\title{
Correction to: "Don't Mess with Me!" Enacting Masculinities Under a Compulsory Prison Regime
}

\section{Nick de Viggiani}

\section{Correction to:}

Chapter 5 in: M. Maycock, K. Hunt (eds.), New Perspectives on Prison Masculinities, Palgrave Studies in Prisons and Penology, https://doi. org/10.1007/978-3-319-65654-0_5

Author name was incorrectly captured in particle tag while it should be part of family name and the correction has been updated in book.

The updated online version of this chapter can be found at https://doi.org/10.1007/978-3-319-65654-0_5 